\title{
CHRISTIANITY IN UGANDA
}

STANLEY's challenge to the Christian world to send forth missionaries to the Court of Mutesa appeared in the columns of the Daily Telegraph of the 15 th November 1875 , and probably no single letter to a newspaper has ever brought about such extraordinary results. The sum of $£ 24,000$ was almost immediately offered to the Church Missionary Society for the establishment of a special mission in Uganda. The missionaries occupied the new land, converted the heathen inhabitants with a rapidity that startled Christendom, and but for the unfortunate sectarian differences which arose a little later, the story of the Uganda Mission would doubtless have been the most brilliant record of the spread of the Gospel in the annals of the world. The check that the work received from an unexpected quarter and the long years of terrible bloodshed and civil war that resulted therefrom are matters of such interest as to be worthy of being told at length.

In the spring of 1876 the Church Missionary Society had completed its plans, and the pioneer party, consisting of eight members, ${ }^{1}$ left England, reaching Zanzibar in June. Thence they proceeded on their way to Uganda, but before leaving the coast the misfortunes of the little band had commenced. One of the artisans died, the two others were invalided home, and Mackay's health forced him to remain behind near the coast. The remainder of the party reached the southern end of the Victoria Nyanza after an arduous march of many months, and before embarking for the capital was further reduced by the death of Dr. Smith. Wilson and Shergold Smith eventually arrived at Mutesa's Court on the 3oth June 1877 (O'Neil having

1 Lieut. G. Shergold Smith, R.N. ; the Rev. C. T. Wilson; Mr. T. O'Neil, architect; Dr. John Smith, Edinburgh Medical Mission; Mr. A. M. Mackay; and three engineers or artisans. 
remained behind in charge of the stores of the expedition), and the reception accorded the missionaries by the king exceeded all their expectations. He expressed himself as eager to learn all about Christianity, and Wilson remained at the capital to preach the Gospel, while Shergold Smith sailed down the lake to bring up O'Neil and the stores. In December I877, Shergold Smith and O'Neil were murdered by the natives of one of the islands of the lake, and Wilson was left, the sole survivor of the party, to carry on the great work. Mackay, however, who during his enforced stay on the coast had been doing good service, joined Wilson in Uganda in November I878, and in the following spring reinforcements had arrived from England, Pearson, Litchfield and Felkin having proceeded thither by way of the Nile, while another party followed the route of the pioneers from Zanzibar.

For a time no less than seven Protestant missionaries were at work in Uganda, and the king and his people were soon convinced of the advantages of Christianity. The missionaries were confident of success, and the day when Mutesa should for ever throw off the pagan yoke and embrace the new faith was awaited with sanguine eagerness. To have converted the king would have carried with it the immediate establishment of Christianity in Uganda ; the old heathen customs would have been broken down, and the entire country would have been revolutionized. It was, however, not to be ; for, at the very moment when the Protestant missionaries were on the point of reaping the reward of their labours, two influences arose to check all progress. The Arab traders, whose caravans plied between Uganda and the coast, saw the danger of allowing Mutesa to be persuaded by the Christians, and, fearing a loss of power at the Court, did all in their power to undermine the hold which the Englishmen had obtained over the king. Whose arguments would have prevailed with the heathen monarch it is impossible to say, but the arrival in Uganda of a party of French Roman Catholic missionaries (Algerian Mission) soon decided the fate of the Christians. As was only natural, Mutesa, on hearing from the Romish priests that their views were not in accord with those of the Protestant

'A. M. Mackay: Pioneer Missionary of the Church Missionary Saciety to Uganda. By his Sister. 1890. 
missionaries, became perplexed, and at once proclaimed the whole Christian Church an imposture. He, however, still maintained his friendship towards his old guests, the Protestants, and, in June 1879, despatched three envoys to England in charge of Wilson and Felkin.

For a while Uganda wavered between the Cross and the Crescent ; the arguments of the advocates of each faith seemed almost equal, though Mackay found it easy when confronted with his adversaries to defeat them on all points. He was a man of many parts, and his early training as an engineer soon brought him immense popularity as a "handy man"; his workshop was beset by the natives at all times, and their faith in the white man's knowledge knew no bounds. Islam was defeated, and, for a second time, the missionaries imagined that the evangelization of the country was on the eve of becoming an accomplished fact ; but a second time they were doomed to disappointment. This was in December 1879, when a wave of paganism passed over the land, obliterating, for the time, all traces of the good work done by the missionaries. "It is heartrending," wrote Mackay, in one of his letters home, "to think of this result of more than two and a half years' teaching of Christianity at this Court." The cause of the new trouble was the state of health of Mutesa, who for two years had been suffering from an incurable disease, and who had now been persuaded by his female relatives to seek the advice of a wizard or medicine man, professing to have intercourse with the lubare, or spirit, of the great Nyanza. Mackay fought with all vigour to prevent the introduction of the medicine man into Uganda, but owing to the weak character of the king and the influence of the women, his efforts were of no avail, and Mukasa, the seer, was accommodated in the royal enclosure. Mutesa acknowledged from the first that he had no faith in a cure by charms, but at the same time he seems to have believed that his destiny was controlled by the spirits of his departed ancestors, and that there were certain persons who were able to hold converse with these spirits. ${ }^{1}$

1 "Every dead king has a Maandwo, who makes all believe that the spirit of the late monarch has entered into him, or does so periodically. On chese occasions he raves frightfully, talking in a strange falsetto voice, when people bring pots of mwenge (beer), for the musinu (spirit of the departed) is believed not to eat, but to drink plentifully." Mackay. 
The pagan influence soon became supreme, and the people were forbidden to hold intercourse with either Christians or Mohammedans : then, urged on by the rabble of heathen priests, Mutesa gave way to every form of brutality and vice. His executioners were placed on every road with orders to kidnap, each day, a certain number of passers-by for the morning sacrifice. Scores of innocent natives were slaughtered at sunrise : the bloodthirsty agents scoured the country, far and wide, for victims ; and on certain great occasions, the king proclaimed a kizvendo, when two thousand human beings were slaughtered at one time. The one aim and object of all these atrocities was the cure of the king's disease (stricture), and seeing, at length, that the pagan doctors were unable to effect this, Mutesa called in the services of an Arab, and, later on, of the French Roman Catholic missionaries, but both resulting in failure, he returned again to the human sacrifice treatment, which, if not producing a cure, at any rate soothed his troubled spirit. That he was easily persuaded seems certain, for at one time he had commanded his subjects to embrace Islam; at another he was almost a Protestant ; and again, the "White Fathers" imagined they had secured him. At heart he was a pagan, and a cruel and licentious ruler, and his death on the roth October, 1884, was not a matter of regret to Christians, Mohammedans, or heathens.

To go back a little. The last years of Mutesa's reign had witnessed extraordinary religious changes in the country. The Mohammedan party had greatly increased; almost a hundred natives had been baptized by the Protestant missionaries, and the Roman Catholics had been working steadily to gain converts to their creed. There thus existed at this time three distinct alien creeds, whose followers became absolute fanatics, Roman Catholics and Protestants hating one another with a fervour only equalled by their joint hatred for Mohammedans. Had the Christian missions combined and been content to work on broad-minded principles, Uganda might have been saved years of bloody warfare. But from the outset a bitter jealousy sprang up between the French and English missionaries, each party endeavouring to undermine the other, with the most fatal results to both. The religious future of Uganda was 
hanging in the balance; the feelings of the heathen inhabitants had been worked up to a change; like the Japanese, they desired to renounce their ancient beliefs; but it was difficult to decide what new creed would suit them best. Mohammedanism had many points in its favour; it permitted polygamy, slavery, and a certain latitude in the matter of charms and reverence for spirits, but on the other hand the Christian missionaries had proved themselves far superior to the advocates of Islam. Still, there was a split in the Christian camp, which was perfectly inexplicable to the pagan, and he began to doubt. At whose door-whether Roman Catholic or Protestant-the blame is to be laid it is not necessary to discuss, though treating the matter from a purely non-sectarian point of view it can be regarded only as most lamentable.

Up to this time reinforcements had been continually despatched to Uganda by the Church Missionary Society, and shortly before Mutesa's death James Hannington had been consecrated first Bishop of Uganda. The embarrassment caused by the presence of the French missionaries had been temporarily removed at the end of $\mathrm{I} 882$, when, after a residence of three and a half years in the country, the "White Fathers" quitted Uganda, and the English missionaries seized the opportunity to redouble their energies among the native population.

Mutesa was succeeded by his son Mwanga-a lad of eighteen-who was well-disposed towards the missionaries, or appeared to be so. He even asked that more missionaries might be sent to Uganda, and invited the "White Fathers" to return, probably for the sake of the presents which he knew that they would bring. Be that as it may the fact remains, that within two months of his accession to the throne, Mwanga had denounced all alien religions as destructive to the welfare of his kingdom, and threatened both Mohammedans and Christians with extermination. The Protestant missionaries, Ashe, O'Flaherty, and Mackay were seized, and three of the native converts were roasted to death. Then followed the murder of Bishop Hannington, on his way to the capital from the coast; and in May, 1886 , the persecution of the native Christians increased, no fewer than thirty-two being burned 
alive on one pyre. "In spite of martyrdom by torture and burning," says Lugard, "the religion grew, and converts came to be baptized, though they knew that the profession of the Christian faith might cost them their lives on the morrow."

In June, 1886, there were in Uganda the two Protestant (English) missionaries, Mackay and Ashe, and two Roman Catholics (French). Ashe left in August, but Mwanga refused Mackay permission to depart, and he remained at his post alone for a year, during which time the persecution of the Christian converts continued uninterruptedly, until eventually they fled from the capital in all directions. At length, in July 1887, Mackay left Uganda and went to the south of the lake, being relieved at his post by the Rev. E. C. Gordon, who was joined in the following April by the Rev. R. H. Walker.

Mwanga now changed his bearing towards the missionaries, and went so far as to encourage them in their work. Protestants, Roman Catholics, and even Mohammedans were permitted to go about unmolested, though it soon became evident that the king had formed a plan for ridding his country once and for all of their presence. In August 1888, the plot was discovered, and the three parties joined in a common revolt, and marched on the capital, with the result that Mwanga immediately took flight, and was deposed. Kiwewa, Mwanga's brother, was placed on the throne, and the chief offices were taken over by the Christian converts, while the minor ones were given to the Mohammedans. This was a somewhat faulty arrangement ; for, as was only natural, the Mohammedan party - far stronger than the Christian-became jealous, and in October attacked the Christian chiefs unawares and ruthlessly murdered them. Panic seized those of the native Christians who escaped massacre, and they fled to Ankole; while the missionaries (both English and French) were seized and sent away down the lake.

The Mohammedans (Arabs) were now masters in Uganda, but they failed to induce Kiwewa to become a convert, though they soon succeeded in driving him from the country, when they placed another brother, Kalema, on the throne.

This brings us to the middle of 1889 , when the European

1 The Rise of our East African Empire. 1893. 
missionaries who were living on the southern shores of the Nyanza, and the Christian converts who had found a refuge in the kingdom of Ankole, determined to offer the fugitive Mwanga the chance of recovering his lost kingdom. They promised, under certain conditions, to support him with their arms, and the pagan population of the Nyanza islands (smarting from the oppression of the Mohammedan rule in Uganda) threw in their lot with Mwanga. War was declared, but the Mohammedans were too strong for their opponents, and the Christians were defeated and put to flight. Later in the year however the Christians, having received a fresh supply of arms, renewed the attack, utterly routed the Mohammedans, seized the capital, and reinstated Mwanga.

So far the two Christian parties, equally oppressed and in trouble, had been content to consider themselves merely Christians, and to work together for the expulsion of the common foe. Now however that this was accomplished, there commenced the unfortunate sectarian differences to which reference has been already made. It would be unfair to ascribe these differences entirely to the few European missionaries, for it must be remembered, that each of the two factions (Protestant and Roman (atholic) consisted of a number of the native chiefs and their followers who had become converts to Christianity and were naturally jealous of one another. Still, the European missionaries must be considered to have been the responsible heads of their respective factions, and that the natives regarded them as such is evident from the fact that they usually obeyed them-even when their blood was up for a fight.

At Mwanga's restoration, the Christian chiefs divided the country and the offices of state, and each party at once set to work to plot against the other. The King himself professed to be a Roman Catholic, and was certainly much under the influence of Pere Lourdel, but at the same time he had come to regard it as a matter of importance for the safety of his throne that Europeans (with their superior weapons) should be induced to come to Uganda, whatever their denomination. Had the Roman Catholic missionaries been fellow-countrymen of the Protestant missionaries, it is quite possible that all differences 
would have been sunk in the desire to uphold British prestige, but that the "White Fathers" were French undoubtedly increased the jealousy of the European leaders of the two factions, who now distinguished themselves, not as Roman Catholics and Protestants, but as French and English (Wa-Fransa and Wa-Ingleza).

For the moment, however, there was little time for either party to gain much advantage, for within a month of Mwanga's return the Christians had to combine to resist a Mohammedan attack. The Christians were defeated, and forced to take refuge on the islands of the Lake, though in February, 1900, they turned the tables on the Mohammedans and recaptured the capital.

It was at this time that the British East Africa Company decided to extend its operations to Uganda, and Mr. Jackson arrived in the country, to endeavour to make a treaty with Mwanga. The king however, at the instigation of Pere Lourdel, refused to agree to the proposed terms, the Roman Catholics supporting the king, and the Protestants siding with Jackson. Seeing that he could not get his way, Jackson decided to leave his deputy (Mr. Gedge) in Uganda with the arms that he had brought up, and return to the coast to make further arrangements. The Wa-Ingleza said that they would depart with Jackson and abandon Uganda, but no sooner was this known than the Wa-Fransa determined that, being too weak to stand alone against the Mohammedans, they would also accompany Jackson. Eventually it was decided to send a representative of each faction to the coast to find out whether the English or the French were about to establish a protectorate over Uganda.

The Protestants and Roman Catholics were at this juncture only restrained from attacking each other by scarcity of arms and ammunition, and by the fear that civil war would give the Mohammedans the opportunity of once more seizing the country, and massacring all Christians. Mwanga's sole idea was to obtain arms by fair means or foul, and he was quite prepared to risk a civil war in the hope that the Wa-Fransa would be able to capture the arms in the possession of Mr. Gedge. Gedge had instructions to avoid all possibility of a conflict, but 
if such appeared probable, he was to take the Wa-Ingleza to Usoga.

In May 1900 Père Lourdel died, and later in the year Lugard, on behalf of the Chartered Company, proceeded to Uganda in order to come to terms with the king, whose country had now by international agreement been placed under the influence of Geeat Britain. Lugard's task was no light one; his mission had for its objects not only to make a treaty with Mwanga, but to maintain peace between the Wa-Ingleza and the Wa-Fransa, to settle the country, and practically to assume control over it. Hitherto all Europeans who had visited Uganda came laden with presents, and showing great deference to the king; Lugard's arrival (December, 1900) was entirely different; he marched his armed caravan of some 250 men straight on the capital, pitched his camp, and sent a polite message to Mwanga, fixing his own time for a visit.

After every conceivable objection on the part of the Roman Catholic faction, the treaty was eventually signed, but even then the disputes between the Wa-Fransa and the Wa-Ingleza increased rather than diminished each day. The differences were semi-political, semi-religious, and they arose from the original agreement that the Christians had made on restoring Mwanga to the throne, viz., that the Protestant chiefs and the Roman Catholic chiefs should share equally in the offices of the State, but that if a chief changed his religion he should forfeit his rights and his lands.

Bishop Tucker and three new Protestant missionaries reached Uganda a few days after Lugard's arrival, and during the month that the Bishop remained in the capital many converts were made. In March, 1901, the number of Protestants was estimated at 2000 adherents, though these probably included the irresponsible followers of Protestant chiefs, for the actual numbers were recorded as two hundred baptized Christians and sixty communicants. There were, however, $2000 \mathrm{Wa}$-Ingleza ready to fight for their cause; while on the other hand the Wa-Fransa faction was superior in numbers, and was moreover backed up by Mwanga. Lugard, though a Protestant, remained absolutely unbiassed, so much so in fact that the Wa-Ingleza on more than one occasion taxed him with favouring the Wa-Fransa. 
The story of the following year (1891) is one of constant disputes, preparations for war between the Protestants and Roman Catholics, threatened night attacks, and minor outrages. That civil war was averted early in the year was due entirely to Lugard's personal influence and diplomacy; though the appearance of the common enemy, the Mohammedans, on the borders of the country in the spring somewhat relieved the situation. All attention was now paid to war with the Mohammedans, and both factions, assisted by Lugard and his porters, took the field in April. By the middle of May the Mohammedans had been defeated and the war was at an end, but Lugard did not return to Mengo (the capital) until some months later. During his absence on important work in the neighbouring provinces Captain Williams was left in charge of Uganda, and it was with the greatest difficulty that he was able to restrain the rival Christian parties from attacking each other.

Mgr. Hirth, the head of the Roman Catholics, had taken the place of Père Lourdel as Mwanga's secret adviser, and moreover he endeavoured to persuade Williams that, if peace were ever to be assured to Uganda, one or other of the two Christian factions must disappear. It is unnecessary to say which party $\mathrm{Mgr}$. Hirth desired should remain. The manner in which the gradual disappearance of the Wa-Ingleza was to be brought about was the repeal of the old law concerning the forfeiture of estates when a chief changed his religion. This had all along been the stumbling-block to the spread of the Wa-Fransa cause, for the Roman Catholic missionaries knew well that many of the Protestant chiefs would naturally like to be on the side of the king, were they able to retain their lands on changing over.

To make a long story short, the law was actually repealed, but before this occurred Mwanga and the Romanists had evidently laid a plot for the extermination of the Protestants, and though the Wa-Fransa had practically obtained what they wished, it was now too late to prevent a conflict. Mwanga had arranged that there should be a rising in Buddu, and he had given orders to the petty Chief of Koki to lead a Fransa army, suppress the rising, and wipe out the Wa-Ingleza. As a matter of fact, however, Koki was utterly defeated by the Protestants, who fougint with the greatest valour. This was 
in July, I89I, and there were various little outbursts in the succeeding months, culminating in a more serious affair in Chagwe (Eastern Uganda) in November. Here in all probability the Wa-Ingleza would have suffered severely, being outnumbered by their opponents, had not a caravan (under Mr. Martin) arrived from the coast and Lugard himself appeared with his force in the neighbourhood of the scene of the impending fight.

At the beginning of 1892 a crisis seemed imminent. Mwanga for the moment doubted the good faith of the Roman Catholic party, and expressed a wish to go over to the Wa-Ingleza, whereupon Lugard suggested that he should declare once and for all for the English and accept the flag of the Company. The king wavered, and finally refused the flag. Fresh troubles soon arose in all directions; a Mohammedan invasion threatened, and had to be checked by the despatch of $W a$-Ingleza and $W a-$ Fransa armies from the capital; then came a new disturbing element in the shape of a powerful pagan rising, having for its object the expulsion from the country of all Mohammedans and Christians, and more particularly of Europeans. But both the Mohammedans and the pagans were soon suppressed, and the country began to settle down again to the old state of political and religious ferment. Even Lugard began to despair of settling matters satisfactorily between the two factions, and he distinctly blames the European missionaries for the state of unrest. "It is not, therefore, to be wondered at," he writes, "that the converts of either religion were animated by the intensest rancour and hatred of each other, since their teachers showed such narrow-mindedness."

Up to the 2oth January, 1892 , there had been no indication of anything more than the usual friction between the $W a-I n g l e z a$ and the Wa-Fransa, but within a few days the storm had burst. A Protestant native was murdered by one of the Wa-Fransa; Mwanga refused justice, and was supported by the Roman Catholic chiefs, as well as by the Fathers; Lugard remonstrated, but received insulting messages in reply. Then the Wa-Fransa beat their war drums, and the country was up. The battle that followed (24th January) was one of the fiercest yet fought in Uganda, and everything points to the fact that the 
Wa-Fransa desired to fight and were absolutely confident of victory. Perhaps the best proof of this is that Mgr. Hirth and his ten Fathers refused to accept the protection of Fort Kampala which Lugard had offered them equally with the Protestant missionaries, when he saw that there was small possibility of averting a conflict.

But for the insulting boast of Mwanga and the Wa-Fransa chiefs that after defeating the Wa-Ingleza Fort Kampala should be stormed and looted, probably Lugard and his Company's men would have held aloof from the battle ; now, however, they were forced in self-defence to support the Wa-Ingleza. Without entering into the details of the fight, it will be sufficient to say that the result was a surprise even to Lugard, for the Wa-Fransa were completely routed and driven from the field; the Roman Catholic church, the dwellings of the Fathers, and the huts of the WaFransa were set on fire; and Mwanga fled for his life. It is, however, satisfactory to know that none of the European missionaries took an active part in the day's work, and when the fight was ended, Lugard rode over to the Roman Catholic Mission Station and escorted the Fathers to Kampala, where he entertained them as his guests.

Mwanga had taken refuge on an island of the Lake at no great distance from the capital, and Lugard at once endeavoured to induce him to retum, telling him that he "had no quarrel with him," and that it was all-important that he should look after his kingdom, so that the Mohammedans and pagans should not seize it. Mwanga however was afraid to return, and two days after the fight Mgr. Hirth, contrary to Lugard's wish, decided to visit the king on his island. With him went eight of the Fathers (two remaining at Kampala for another day), and Lugard sent porters and an escort with them, assisting them thus under the impression that they intended to persuade the king to return and bring about a settlement. In this he was bitterly disappointed, for he soon heard that the French missionaries were hand in glove with Mwanga and the Wa-Fransa, and not at all anxious for a reconciliation.

On the 29th January a fresh outrage was committed by the Wa-Fransa, who burned some Protestant dwellings on the shore of the Lake, and failing to get satisfaction Lugard proceeded to 
attack Mwanga's place of refuge and clenred out the Wa-Fransa. Mgr. Hirth and Mwanga escaped together in a canoe, while the rest of the Fathers were escorted in safety to Kampala, where they received every hospitality. After these events nothing particular happened for some little time, though what with the Wa-Fransa, the Mohammedans, and the want of a king, the state of anxiety was intense.

Towards the end of February, 1892, an expedition was sent to capture the Sessé Islands, and early in March the Fathers left Kampala, in order to rejoin the Wa-Fransa and attempt to induce Mwanga to return before the Mohammedans got possession of the country. The Wa-Ingleza alone were not strong enough to hope to resist a Mohammedan invasion, and Lugard, aware of this, was temporizing with the Mohammedans and contemplating, in the event of Mwanga's continued absence, the establishment of Mohammedan rule in Uganda. Had this actually occurred, Christianity would probably have disappeared from Uganda altogether, and Mgr. Hirth now grasped the situation, though hitherto he had hoped that, by keeping Mwanga away and allowing the Mohammedans to attack and destroy the Wa-Ingleza, the Wa-Fransa would be able to drive out the Mohammedans and become paramount in Uganda.

On the 3oth March Mwanga returned to his capital, and threw himself on Lugard's mercy. Lugard received him as if nothing had happened, and the Roman Catholic and Protestant missionaries and chiefs welcomed him as the ruler of the kingdom, hoping that his return meant peace in the land. Negotiations at once commenced, and on the 5 th April the treaty of peace between the Wa-Ingleza and the Wa-Fransa was concluded. By its terms the country was divided between the two factions, Buddu and certain islands being handed over to the Wa-Fransa. A week later was concluded a further treaty, by which Uganda was placed under the protection of the Imperial British East Africa Company, and all parties, Wa-Fransa, Wa-Ingleza, and Mohammedan, eagerly accepted the British flag. As was only natural, for some little time the two Christian factions put forward claims and counter-claims, but Lugard himself now dealt with such matters, and when he left Uganda 
in June, he had the satisfaction of feeling that he had established between the Roman Catholics and Protestants a peace that had every prospect of being a lasting one. "Lugard," writes Sir Harry Johnston," "effected very wonderful things with very small resources. It will be some. time yet before the greatness of his exploits is thoroughly realised."

From this time dates the spread of Christianity in Uganda, for the missionaries no longer dreading war were able to set to work with comparative freedom of action. The Mohammedans, like the Christians, were given a district in which to reside, though as long as they were peacefully disposed they were permitted to go where they pleased. As has been pointed out, the number of actual converts to Christianity prior to the war was probably small, and the bulk of the fighting force on each side consisted of the followers of chiefs who were themselves either Roman Catholic or Protestant converts, or for political reasons professed to be so. Now everything changed, and the record of missionary work during the last decade can only be described as most brilliant. In place of actual warfare, there set in a healthy religious rivalry between the missionaries; and though there is nothing to show that the Protestant missionaries and the Fathers were ever on friendly terms, at the same time there was no open rupture.

With regard to the Protestant Missions, Bishop Tucker visited Uganda at the end of 1892 , and on Christmas Day preached to a congregation of 5,000 natives in a new church, that had been erected on Namirembe hill. In the following May he "admitted six natives to deacons' orders, licensed ten lay evangelists, and confirmed I4I candidates." 2 During 1894 immense strides were made in spreading the Gospel, not only in Mengo, but also in the outlying districts ; nearly 150 teachers were distributed throughout the country, and supported either by the chiefs or by public subscription; upwards of 200 churches were erected in various parts, with congregations estimated at a total of not less than 20,000 , and the natives purchased 12,000 copies of scriptural translations. By the arrival, in 1895, of several new missionaries and five English

1 The Uganda Protectorate, London, 1902.

2 Church Missionary Atlas, Part I., 1896. 
lady workers a further impetus was given to the work, which thenceforward continued to make considerable progress year by year, until in 1901 we find the following statistics recorded:Total European staff, 59 (22 clergy, 2 medical missionaries, 13 lay missionaries, and 22 ladies); stations occupied by the C.M.S., 20 ; native staff, 27 clergy, 53 licensed readers, 2,408 native teachers.

No less prosperous have been the efforts of the Roman Catholic missions, for not only have the White Fathers (French) continued their work, but an English mission (Mill Hill College) has also been established. The number of Roman Catholic stations in the different districts is now seventeen; there is at the capital a fine stone cathedral, and elsewhere some 450 places of worship. But it is not by mere preaching that the advantages of Christianity are brought home to the people of Uganda ; both the Protestant and the Roman Catholic missions have established a most thorough educational system, under which thousands of native children are instructed at any rate in the "Three R's," pupil teachers are trained at certain centres, and advanced teaching is given to native lads who are desirous of becoming clerks, \&c. A special feature of the Protestant mission is its industrial schools, at which many useful trades are taught; and the medical and hospital work carried on by the English and the French missions is so excellent that, even were there no question of religion, the native would be forced to confess that the presence of the white man was essential to his very existence.

From what has been related above it will be apparent that Christianity in Uganda is an established fact ; that Uganda is to all intents and purposes at the present time a Christian kingdom, and that it became such more by good fortune than by good management, for but for the presence of a layman (Lugard) at the critical time, in all probability the Christians in Uganda would have exterminated themselves. However, the great fact remains that the Cross in this part of Africa forestalled the Crescent, and now that the whole of the Continent is being rapidly opened up, it would be well if certain lessons learned from the evangelization of Uganda were borne in mind. It must be remembered that Uganda was an ideal field for mission work-a 
pagan country whose people lived in a state of semi-civilization uninfluenced by the Mohammedans, and ready to accept a religion that could prove itself advantageous to their welfare. The first missionaries were well received by the Baganda, and it is not too much to suppose that had not the White Fathers arrived on the scene, Uganda would have quietly accepted the Cross almost at once, and years of unrest would have been saved, as well as thousands of lives. Still no one can blame the Roman Catholics for going to Uganda-they had as much right to do so as had the members of the Church Missionary Society ; but it is for their narrow-mindedness, and for meddling with politics, that both the Roman Catholic and the Protestant missionaries are to blame, and it is in this latter respect that danger arises from missionaries pushing forward into new fields in Africa.

It is impossible not to admire the pluck of the little bands of missionaries who daily face the dangers of penetrating into unknown countries, but at the same time it is questionable whether they should be permitted to go where their country is unable to protect them. Their doing so has frequently led to costly expeditions, resulting in the deaths of many brave Englishmen and countless natives. "Trade follows the Flag" is a wellknown saying, and it would seem as if should be prefixed to it "The Flag follows the Missionary." Is it right that this should be? Is it the rôle of the teacher of religion to prepare the way for annexation, following after bloodshed? Why should not missionaries restrict their work in Africa to the enormous tracts of pagan country that have been brought under the direct jurisdiction of the several European Powers, instead of endeavouring to rush ahead in search of fresh ground? These and similar questions the layman asks, and the missionary's reply is ever the same-it is his duty to go everywhere, and to take the risk. He does not seek and he does not want the protection of his country; he goes with his life in his hand and his trust in God. Yet Great Britain has hitherto considered it her duty to get missionaries out of difficulties, and will doubtless continue to consider it her duty to do so. For that reason alone missionaries should be chary of involving their country.

A. F. MOCRLER-FERRYMAN, Lieut. Colonet. 